Sarah-Jane Page

School of Sociology and Social Policy

University of Nottingham

University Park,

Nottingham

NG7 2RD

lqxsjp@nottingham.ac.uk

\title{
The Construction of Masculinities and Femininities in the Church of England: The Case of the Male Clergy Spouse
}

\begin{abstract}
The ordination of women to the priesthood in the Church of England in 1994 signified great change. The impact of the new priests was well documented, and their integration became the focus of much research in the following years. One important area of change was the altered dynamics of gender identity. New roles had opened up for women, but new identities had also emerged for men. Whilst women priests were a new historical emergence, so too were clergy husbands. This paper will consider the historical construction of masculinities and femininities within the church and will go on to look at this in the context of clergy spouses, specifically focusing on men occupying this role. Some provisional findings, acting as work in progress, will be considered.
\end{abstract}

Key words: clergy spouse, gender identity, Church of England, masculinities, Church work

\section{$\underline{\text { Introduction }}$}

The emergence of the male non-ordained spouse has only fleetingly been documented but can be framed within a traditional research preoccupation with 'clergy wives' and the somewhat competing construction of masculinity. The article will follow these two threads in the initial literature review, looking firstly at how gender identity has been constructed historically for both men and women, to move on to consider the 
research produced on women as spouses to clergy. The small corpus of literature in existence on male non-ordained spouses will be considered, followed by a discussion of the way in which men are potentially engaging with this new 'role' based on provisional findings that have emerged from some work-in-progress on male nonordained spouses.

\section{The Historical Construction of Gender Identity}

The construction of femininity within the Church of England has a long history, documented extensively by Gill. ${ }^{1}$ The Victorian era was characterised by a number of approaches. The Evangelical tradition held a contradictory view of women - on the one hand, women were self-sacrificing and highly religious, but they were also constructed as disobedient. The Anglo-Catholic tradition followed a similar juxtaposition, yet the contrast was more evidently between Eve and Mary. The Liberal tradition was less theologically bound in their constructions of sexuality, yet their ideals were still dominated by the prevailing middle class theories that men and women were fundamentally different, and that 'women's highest gifts were best experienced in motherhood'. ${ }^{2}$ Gill's analysis effectively showed that the ideas and values placed upon and infused by femininity were never constants, but were underpinned by conflicting ideas for appropriate feminine behaviour. This idea of femininity as an unstable and contingent entity has implications when the status of women is changed in a profound way, as epitomised by their ordination to the priesthood. An important question one could ask is what impact has the ordination of women to the priesthood had on the meanings one ascribes to femininity and identity construction. Conversely, as new roles have opened up to men, in the form of clergy husbands, ${ }^{3}$ how have they adapted and shaped this role, and has the construction of masculinity had any implications for how this role is carried out?

\footnotetext{
${ }^{1}$ S. Gill, Women and the Church of England: From the Eighteenth Century to the Present, (London: SPCK, 1994).

${ }^{2}$ Gill, Women and the Church of England, p. 82.

${ }^{3}$ The term 'clergy husband' has been used as a short-hand for 'male non-ordained clergy spouse' and does not refer to a husband occupying the role of a clergyperson. Others have used the term in this context (S. Walrond-Skinner, S. (1998). Double Blessing: Clergy Marriage Since the Ordination of Women as Priests, (London: Mowbray, 1998). It should also be noted that the terminology surrounding non-ordained spouses is problematic, in that by articulating the notion of 'clergy wife' or 'clergy husband' brings it into being as a salient identity, thus reifying various stereotypes. Where possible, the
} 
Masculinity as a concept has been little documented in terms of the church, but it can be observed that masculinity has been naturalised so that its existence is not selfevidently manifest. It is only when the presence of women's bodies disrupts this naturalised order that masculine identity comes to be noticed. Whitehead ${ }^{4}$ argues that $^{-}$ men gain their sense of identity through the colonisation of the public sphere and its institutions. These sites of male privilege and power offer 'validations of masculinity, heterosexuality and brotherhood'. ${ }^{5}$ This is explicitly made on the basis of the exclusion of women. Because women have previously not been integrated into church structures (apart from at the level of deaconess - a position in church which was continually perceived as anomalous ${ }^{6}$ the cultural climate is overwhelmingly masculinist. As Aldridge argues, 'the clergyman is integrated into the Church's organizational structure. There are frequent meetings with brother clergy for him to attend and there are many clerical societies for him to join'. ${ }^{7}$ The emphasis here is on fraternity. The Church of England has operated an overwhelmingly masculinist institution and the admission of women to these orders creates enormous conflict at the ideological level.

Whitehead's emphasis on the masculinist enterprise is extremely useful in mapping and theorising the way the church structures can be perceived to be gendered. Women have now been able to become ordained for more than ten years, yet the masculinist climate may linger, at a cost to their identity.

It would be useful to connect this idea of gender identity as changeable to the work of Connell, ${ }^{8}$ who is concerned with how gender identity is forged and enacted, and who theorises through the concepts of hegemonic masculinity and emphasised femininity. He argues that gender and the roles deemed appropriate to each gender are socially constructed, highlighting that there are numerous masculinities and femininities one

term 'non-ordained spouse' has been used, but when it is important to distinguish between the gender of a person, the terms 'clergy wife' and 'clergy husband' have been adopted, if somewhat reluctantly.

${ }^{4}$ S. M. Whitehead, Men and Masculinities. (Cambridge: Polity Press, 2002).

${ }^{5}$ Whitehead, Men and Masculinities, p. 120.

${ }^{6}$ See A. Aldridge, 'Men, Women and Clergymen: Opinion and Authority in a Sacred Organization', The Sociological Review vol. 37 no. 1, 1989, pp 43 - 64.

${ }^{7}$ Aldridge, 'Men, Women and Clergymen, p. 55.

${ }^{8}$ R. W. Connell, Gender and Power. (Cambridge: Polity Press, 1987). 
can perform. However, there is usually a 'hegemonic' or dominant masculinity in operation perceived to be the ideal. This hegemonic masculinity is more of a mythical archetype, built on heterosexuality and the subordination of women to men. Connell's idea of 'emphasised femininity' captures the gendered opposite of this, ${ }^{9}$ linking women firmly with the home. However, Connell asserts that hegemonic masculinity binds men together in a collective enterprise in a way that emphasised femininity does not, due to the ways in which power is distributed. Connell argues that in many ways, men supervise the ways in which femininity is managed, through the way it is presented through the media and other powerful outlets.

This idea of gender identity as contingent has been further explored in the work of the poststructuralist philosopher, Judith Butler. ${ }^{10}$ She sees gender as performativity - an activity that has to be constantly re-enacted in order to legitimise one's gender identity. This highlights how gender identity is unstable, and how gender can be easily 'troubled'.

These theoretical underpinnings inform much of this research project into the subject area of masculinities and femininities when considering women priests and their partners. There is not the space to discuss all elements of this research, but focus will be placed in this paper on masculinities and the male clergy spouse and the way this topic has been a neglected area of investigation.

\section{The Clergy Spouse: A Brief Literature Review}

In order to map the relevant literature field it is necessary to focus firstly on research on clergy wives, as traditionally, they have been the focus of research. This is despite the fact that in many church traditions, women have been ordained to the priesthood (especially in America) for some years, making such studies on male spouses easily possible.

\footnotetext{
${ }^{9}$ D. M. Kelly, S. Pomerantz, and D. Currie, (2005). 'Skater Girlhood and Emphasized Femininity: "You can't land an ollie properly in heels”, Gender and Education vol. 17, no. 3, 2005, pp 129 - 148.

${ }^{10} \mathrm{~J}$. Butler, Gender Trouble: Feminism and the Subversion of Identity, (London: Routledge, 1999).
} 
Early studies by Douglas and Denton ${ }^{11}$ on the wives of clergy were followed by an explosion of interest in this topic in the 1980s. Mace and Mace, for instance, undertook a study of over three hundred clergy couples from a variety of American denominations, oriented within a counselling perspective. ${ }^{12}$ It highlighted the pressures that clergy families were facing, including heavy work loads, unreasonable demands made by parishioners, lack of privacy, and low salaries. As a study of clergy spouses was not the centre of investigation, much detail is missed and like many studies of this generation, no reference is given to women clergy and male spouses (even though this is an American study, where women had been allowed ordination for some years).

One of the most important studies in the British context was conducted by Finch , who undertook a qualitative investigation, assessing the current role of clergy wives within four Christian denominations (Anglican, Methodist, Baptist and United Reformed Church). ${ }^{13}$ She argued that wives of priests are under immense pressure to become part of a defined role within the church, with tasks ranging from cleaning the church, to running coffee mornings and the Mother's Union. These tasks were perceived to be in-keeping with the skills and competencies of women. Finch (1983) highlighted how the unpaid work conducted is generally asymmetrical, in that the work is constructed for wives and not spouses, as it is those skills women are traditionally seen to be good at which are utilised. ${ }^{14}$ This has implications for studying clergy husbands, and suggests that clergy husbands in the contemporary climate would be less likely to be incorporated into a demarcated role, for it goes against the grain of what is deemed appropriate for masculine behaviour. Finch argued that the clergy wife role is institutionalised, in that to refuse to engage with the tasks would challenge the whole ideological basis on which the constructed identity of the clergy wife is based and would damage the credibility of her husband's work. ${ }^{15}$

\footnotetext{
${ }^{11}$ W. Denton, The Role of the Minister's Wife, (Philadelphia: Westminster Press, 1962); W. Douglas, Minister's Wives, (New York: Harper and Row, 1965).

${ }^{12}$ D. R. Mace, V. C. and Mace, 'Marriage Enrichment for Clergy Couples', Pastoral Psychology vol. 30, no. 3, 1982, pp $151-159$.

${ }^{13}$ J. Finch, 'Devising Conventional Performances: The Case of Clergymen's Wives', Sociological Review vol. 28, no. 4, 1980, pp 851 - 870.

${ }^{14} \mathrm{~J}$. Finch, Married to the Job: Wives' Incorporation in Men's Work, (London: George Allen and Unwin, 1983).

${ }^{15}$ Finch, 'Devising Conventional Performances', p. ?? - it would be useful to have a page ref. here.
} 
This incorporation into the work of husbands is not isolated to ministry. Papanek finds evidence of the two-person career (where there is one salaried post but assumptions are made that the unpaid spouse is available for work) in occupations ranging from business management to academia. ${ }^{16}$

In America, in the same year as Finch published some of her findings, focus was placed on whether the clergy wife role was changing - were wives resisting and rejecting the traditional two-person career, and the label of unpaid curate? Niswander and $\operatorname{Min}^{17}$ aimed to chart the way in which the clergy wife role has undergone a modernising process in the United Methodist Church, with the principal point being that clergy wives no longer derive their sole identity from being the wife of a priest. What the authors did not deny, however, was that clergy wives were 'still experiencing a substantial amount of internal and external pressure and conflict, whether or not they have careers of their own' ${ }^{18}$ It is interesting comparing the work of Niswander and Min and Finch for both come to very different conclusions. One problem with Niswander and Min's study was that their conclusions were based on anecdote and what they could see 'on the ground' rather than on systematic study. Finch's discussion of the institutionalised nature of the clergy wife's role would indicate that it is not such an easy identity to discard, in the way that Niswander and Min imply.

Clergy wives have continued to receive attention, especially in psychological approaches. McMinn et al, for instance, highlighted that clergy wives could experience a large number of stressors including frequent moves, a 'fishbowl' existence, pressure to be an ideal wife and mother, no control over living accommodation, financial strain, loneliness and so on. The authors argued that both clergy and their wives did a good job at managing these issues. ${ }^{19}$

\footnotetext{
${ }^{16}$ H. Papanek, 'Men, Women, and Work: Reflections on the Two-person Career.' The American Journal of Sociology vol. 78, no. 4, 1973, pp 852 - 872.

${ }^{17}$ B. J. Niswander and D. Min, 'Clergy Wives of the New Generation', Pastoral Psychology vol. 30, no. 3, 1982, pp 160 - 169.

${ }^{18}$ Niswander and Min, 'Clergy Wives of the New Generation', p. 163.

${ }^{19}$ M. R. McMinn, R. A. Lish, P. D. Trice, A. M. Root, N. Gilbert and A. Yap. 'Care for Pastors: Learning from Clergy and their Spouses’, Pastoral Psychology vol. 53, no. 6, 2005, pp 563 - 581.
} 
Although this study was one of the most recent on clergy spouses, it is striking how the traditional binary of husband as pastor and wife as helper is alluded to. No acknowledgement is made that spouses could be male.

So why is there a lack of attention within the research to situations where the clergy spouse is male? It could be argued that this is a result of a time lag - in England, the Church of England did not start ordaining women until 1994. However, other church traditions in the UK (e.g. United Reformed Church, Methodist Church) have a longer history of ordaining women, indicating that this research could have been undertaken. Similarly in America there is a longer history of women in priesthood, and many of the above studies discussed are American in orientation. However, it is often the case that studies investigating clergy families do not justify why their research is based on the traditional model.

There are only a handful of studies that have considered men as spouses. Francis and Robbins' study on the women who were deacons prior to the legislation allowing women to be ordained to the priesthood in the Church of England made some comments, articulating that the husbands of these deacons were supportive of their wives' vocation, but a significant number were resentful at the amount of their wife's time spent undertaking clerical duties. Francis and Robbins argued that it was too early to say what the role of the 'clergy husband' was, indicating that more in-depth research needed to be conduced. ${ }^{20}$

Rose , too made brief references to clergy husbands, arguing that clergy husbands have no tradition to follow, but society expects the husband's career to take precedence. She claimed that: 'Unlike the case of the clergy wife, it is not expected that the clergy husband will be the unpaid curate' ${ }^{21}$

One author who has incorporated clergy husbands into her actual research is WalrondSkinner. ${ }^{22}$ This study was principally concerned with clergy marriages - where both

\footnotetext{
${ }^{20}$ L. J. Francis and M. Robbins, The Long Diaconate 1987 - 1994: Women Deacons and the Delayed Journey to Priesthood, (Leominster: Gracewing, 1999).

${ }^{21}$ J. Rose, 'What Difference is Women's Priesthood Making to the Church of England?' in H.

Wakeman, Women Priests: The First Years, (London: Darton, Longman and Todd Ltd., 1996) p. 145.

${ }^{22}$ Walrond-Skinner, Double Blessing.
} 
husband and wife were ordained - but some data was gathered on women priests married to lay husbands within the Anglican Church. Her main finding was that spouses are generally very supportive of their wives, often placing their career ahead of their own. This couple-type were also more likely to be egalitarian in sharing household chores and childcare (compared to dual-clergy couples and couples where only the husband was ordained). Walrond-Skinner highlighted that it is difficult for couples where expectations have changed - ordination has often occurred after marriage - and these husbands would not have had the expectation that their wives would eventually be ordained (even if, purely for the reason that the church did not allow the ordination of women at this point). Therefore, potentially, these marriages could be put under enormous strain, as the expectations have profoundly shifted, but in most cases husbands had adapted very well to their wife's priesting.

Walrond-Skinner argued that the non-ordained clergy husband is less likely to be enmeshed into the work of his wife because firstly, he has no role model to follow (and therefore can enact the role in a variety of ways, unconstrained by tradition), and secondly, he is likely to have a professional identity of his own. Having said this, Walrond-Skinner also pointed out that whilst traditional clergy wives tended to dislike being identified as the spouse of the vicar, the clergy husbands openly endorsed this identity.

\section{The Literature in Context}

This research study is concerned with looking at the experiences of clergy husbands, (i.e. the non-ordained spouses of women priests) and how they fit into the organisational structure of the church compared to clergy wives. The literature review above indicates how clergy wives have been incorporated into the church as an unpaid curate, with certain expectations made of them. But the construction of masculinity may enable clergy husbands to have more freedom in choosing the activities they undertake in church and they may not be subject to the same role constraints that clergy wives experience, especially in relation to Finch's idea that the work of wives is institutionalised. There is little specific literature in this area from which to work, therefore, this literature assessment has been primarily focused on clergy wives. At 
the same time, the literature base offers a good comparative climate with which to compare data from clergy husbands themselves.

It is difficult to make cross-denominational comparisons with regard to clergy husbands, as virtually no research has been conducted outside of the Anglican Church. But the literature on clergy wives has shown quite a lot of homogeneity of experience, whatever the Christian denomination, so it can be asserted that there would be some similarities in the experiences of clergy husbands in the Anglican Church and those in other denominations. For instance, Fancher of the Midwest Ministry Development Service in the United States, an organisation that works inter-denominationally, recognises the impact clergy husbands are having, and argues that demands placed upon clergy spouses will be dependent upon the gender of the spouse, in that male spouses may be expected to undertake traditionally masculine activities, such as the maintenance of church property, whilst female spouses may be encouraged to teach Sunday school and be available for undertaking pastoral counselling. ${ }^{23}$ Although there will be similarities in experience between clergy husbands of different Christian denominations, it would be equally important to recognise that differences will exist, but only future research focusing on inter-denominational comparisons will be able to uncover these issues.

\section{The Research Study}

This research project is interested in looking at firstly, the experiences of nonordained wives to see whether they are still engaging with the traditional clergy spouse role, or whether they are forging careers of their own, and becoming independent of the clergy wife identity. Do Finch's ideas on the role of clergy wife as institutionalised still hold? Or have clergy wives developed an independent identity, as argued by Niswander and Min? This will be sought out through a small number of interviews with female spouses, but it is anticipated that the situation will be mixed, with some resisting the 'clergy wife' identity and others still participating in this role in a traditional way.

\footnotetext{
${ }^{23}$ Fancher, S. C. 'Shadow Dancing: Life as a Clergy Spouse.' (1998) http://www.midwestministry.org/shad_dan.html (12 June 2006).
} 
Following this, fifteen male spouses will be interviewed, in order to ascertain whether their role does differ substantially from that of female spouses, and how they have engaged with this new identity.

Some preliminary interviews have already been conducted by the author into this issue, although the data have been collected from women priests and not the spouses themselves. This obviously has implications for how one person's account can represent another, but these data may give a flavour of what may become apparent in the research proper. Respondents were accessed through a diocesan official within a specific diocese in the Church of England. Therefore, the experiences relate to priests within one geographical area. Five priests who were women were interviewed.

\section{$\underline{\text { Provisional Findings }}$}

The first provisional finding is that clergy husbands do have more freedom in rejecting the clergy spouse identity as traditionally lived out by wives. One interviewee, Elaine, argued that a new clergy wife in her parish had had a difficult task in rejecting the path laid down by her predecessor, but that clergy husbands can have a much more fluid identity. As she says:

The previous incumbent of this parish had an absolutely classic wife who was that clergy spouse person. And it's quite hard I think for my current incumbent's wife to cope and deal with that... She has just chosen not to get involved in the way that her predecessor did and the parish, they're fine about that but it's taken them some time to learn that that's not part of it... I don't think there are those expectations in quite the same way when it is a male spouse, I think people are much less inclined just to assume that they'll be doing the tea and so they do make less assumptions anyway. ${ }^{24}$

The second finding relates to the gendered nature of the work available. Anne articulates how the perceived spouse role is a specifically feminine one:

\footnotetext{
${ }^{24}$ From unpublished interview accounts, undertaken by the author in 2005.
} 
The roles that might have been available were women's roles. Not men's roles. So had I been a bloke, had it been reversed, then we would have fallen into that category I guess... It would have been very east to slip into the Mother's Union, children's work, catering, jumble sales.

Elaine went further in actively rejecting any notion of the clergy spouse identity:

Patrick's determinedly not stepped into the role of clergy spouse. He’s resisted it very, very strongly and I suspect very wisely. It used to both amuse and annoy him that he would get invited to events such as Catering for Large Numbers... and he just doesn't go near things like that.

Thirdly, it also became apparent that clergy husbands were much more involved in childcare and household chores. Elaine articulates:

Patrick has done all sorts of things that fathers aren't expected to do like take my daughter to a ballet exam, put her hair in a bun, you know, put on her makeup for a show and all these kinds of very much non-male things because he's equally shared in parenting... If I was married to a different man, life could be very difficult for me.

So whilst there seemed to be a sense of support for their wives as priests, and whilst husbands were quite willing to become involved in childcare and cleaning, and facilitating the activities in the home, they were much less inclined to become actively involved in the church as a clergy spouse. Having said that, all of the husbands were regular church-goers, and did participate in church activities that were of interest to them. As Denise argues,

He is involved in church. But he has his own ministry. He's involved with youth work and runs the sound system for the church, so he’s always involved with services and things but very much his own ministry rather than me feel that I've got to involve him.

Elaine had a similar experience: 
He attends church very happily and he sits on one or two committees that are of interest and you know where his key skills are appropriate... he would never do anything because he's my husband. Because that's not who he is. He is himself. And he holds that very strongly.

Clearly, Elaine's husband does not want to lose his own identity by succumbing to the clergy spouse role. He is adopting roles he deems appropriate for his own interests and does not wish to be compartmentalised into a pre-defined identity, as many women as spouses have experienced historically. A similar theme comes out of Anne's experience when she says that 'he's come to it just as a person, not as the rector's husband... whoever follows would not be able to step into a role that he's carved out because he hasn't'.

This implies that clergy husbands are rejecting the clergy spouse identity, based on a model previously believed to have been forged by clergy wives, and are instead constructing the role they play in their own terms. It also appears relatively easy for them to reject this identity, for the parish does not have the same expectations of them as they perhaps would of a female spouse. This appears to be tied to the way the work available is gendered. Traditional tasks associated with the vicar's wife have been deemed feminine tasks. It is these jobs that the husbands appear to be rejecting - not working in the church per se, for all of the husbands engaged with at least one task in church life.

The question that remains, however, is who is actually doing the tasks traditionally associated with the vicar's wife? One respondent pointed out that if one is not careful, the priest can end up undertaking both roles, indicating that the priest has a more difficult time defining the boundaries of her role. All of the priests spoken to were quite clear on where their role ended, and few had been drawn into the double identity of clergy and clergy spouse. However, the potential to do both was present. Elaine said that the alternative in her life was to recruit volunteers from the parish to undertake these tasks, although it is perhaps likely that this too would follow a gendered format, in that it would be female parishioners undertaking those activities most closely aligned with the role of the clergy wife. The church roles that the husbands of the interviewees did engage with generally appeared to be 'masculine' in 
orientation, such as being responsible for the sound system. Such engagement would not negate any perceived sense of masculine self.

\section{$\underline{\text { Conclusion }}$}

This initial research has highlighted some very interesting issues that could be pursued in future data collection. During this exploratory investigation the husbands themselves were not interviewed. But in the proposed research, this would form part of the data gathered, and it would be interesting to see what the men themselves make of the clergy spouse identity, in order to ascertain the impact that constructed masculinities have on the roles that they participate in. The way in which men in the role of non-ordained clergy spouse orient their identity in church life, and what choices they have open to them in enacting this identity compared to women in this role will be key themes to be pursued. 
Bibliography

Aldridge, A. (1989). 'Men, Women and Clergymen: Opinion and Authority in a Sacred Organization.’ The Sociological Review vol. 37 no. 1, pp 43 - 64.

Butler, J. (1999). Gender Trouble: Feminism and the Subversion of Identity. London: Routledge.

Connell, R. W. (1987). Gender and Power. Cambridge: Polity Press.

Denton, W. (1962). The Role of the Minister's Wife. Philadelphia: Westminster Press. Douglas, W. (1965). Minister’s Wives. New York: Harper and Row.

Fancher, S. C. (1998). 'Shadow Dancing: Life as a Clergy Spouse.' http://www.midwestministry.org/shad_dan.html (12 June 2006).

Finch, J. (1980). 'Devising Conventional Performances: The Case of Clergymen's Wives.' Sociological Review vol. 28, no. 4, pp 851 - 870.

Finch, J. (1983). Married to the Job: Wives' Incorporation in Men's Work. London: George Allen and Unwin.

Francis, L. J. and Robbins, M. (1999). The Long Diaconate 1987 - 1994: Women Deacons and the Delayed Journey to Priesthood. Leominster: Gracewing.

Gill, S. (1994). Women and the Church of England: From the Eighteenth Century to the Present. London: SPCK.

Kelly, D. M., Pomerantz, S. and Currie, D. (2005). 'Skater Girlhood and Emphasized Femininity: "You can't land an ollie properly in heels.”' Gender and Education vol. 17, no. 3, pp 129 - 148.

Mace, D. R. and Mace, V. C. (1982). 'Marriage Enrichment for Clergy Couples.' Pastoral Psychology vol. 30, no. 3, pp $151-159$. 
McMinn, M. R., Lish, R. A., Trice, P. D., Root, A. M., Gilbert, N. and Yap, A. (2005). 'Care for Pastors: Learning from Clergy and their Spouses.' Pastoral Psychology vol. 53, no. 6, pp 563 - 581.

Niswander, B. J. and Min, D. (1982). 'Clergy Wives of the New Generation.’ Pastoral Psychology vol. 30, no. 3, pp 160 - 169.

Papanek, H. (1973). 'Men, Women, and Work: Reflections on the Two-person Career.' The American Journal of Sociology vol. 78, no. 4, pp 852 - 872.

Rose, J. (1996). 'What Difference is Women's Priesthood Making to the Church of England?' in Wakeman, H. Women Priests: The First Years. London: Darton, Longman and Todd Ltd.

Walrond-Skinner, S. (1998). Double Blessing: Clergy Marriage Since the Ordination of Women as Priests. London: Mowbray.

Whitehead, S. M. (2002). Men and Masculinities. Cambridge: Polity Press. 